\title{
Entrepreneurial Traits, Competency, Performance, and Sustainability of Micro- Enterprises in Kelantan, Malaysia
}

\author{
Abdullah Al Mamun, UCSI University, Kuala Lumpur, Malaysia \\ iD https://orcid.org/0000-0002-9713-742X \\ Syed Ali Fazal, University of Science and Technology Chittagong, Bangladesh \\ Wan Nurulasiah binti Wan Mustapa, UCSI University, Kuala Lumpur, Malaysia
}

\begin{abstract}
This study examined the effects of locus of control, tolerance of ambiguity, vision, persistence, and resilience on entrepreneurial competency, performance, and sustainability among micro-enterprises in Kelantan, Malaysia. Adopting a cross-sectional design, the authors collected data from 403 micro-entrepreneurs. The findings revealed that locus of control and vision significantly influenced entrepreneurial competencies. In turn, entrepreneurial competencies, locus of control, and visionary traits significantly affected micro-enterprise performance. The findings also revealed a positive effect of entrepreneurial competencies and performance on micro-enterprise sustainability. The findings also confirmed a significant mediating effect of entrepreneurial competencies on the relationship between locus of control and vision and enterprise performance. The government and developmental organizations should collaborate to enhance locus of control, vision, and resilience traits in order to facilitate micro-enterprise sustainable performance.
\end{abstract}

\section{KEYWORDS}

Competency, Enterprise Performance, Entrepreneurial Traits, Sustainability

\section{INTRODUCTION}

Small and medium enterprises (SMEs) provide job and self-employment opportunities for many households (Kongolo 2010; Simpson, Taylor, \& Barker 2004). Micro and small enterprises also facilitate technological capability building, diffusion of innovations, and capital mobilization (Nabiswa \& Mukwa, 2017). For instance, Al-Mamun, Nawi, and Zainol (2016) highlighted that the activities of micro-enterprises can beef up the national development of Malaysia. A total of 1.3 million individuals (9.7\% of the total workforce) are actively engaged in micro-economic. According to Aziz, Halim, and Wahid (2017), Malaysian micro-enterprises contributed 75 percent to the total SMEs with less than five full-time employees and an annual turnover of approximately RM 300,000. They are involved 
in extremely small business activities such as food and burger stalls, night market vendors, grocery stores, construction, and service contractors.

Individuals should possess unique abilities and personality traits to achieve organizational success (Beattie, 2016; Gartner, 1990). To understand the underlying capabilities and traits, it is crucial for researchers to look into the relationship between entrepreneurs and organizational success (Driessen $\&$ Zwart, 2007), because the value creation process of small firms is highly reliant on the capabilities of entrepreneurs (Grant, 1991). Thus, the Babson's survey considered entrepreneurial traits and characteristics as main focuses (Gartner, 1990).

Entrepreneurial competencies are required by owners to perform entrepreneurial activities in small and new enterprises (Mitchelmore \& Rowley, 2010). Al-Mamun et al. (2016) defined entrepreneurial competencies as the ability to complete a task with available resources to accomplish micro-enterprise performance. For example, Bird (1995) confirmed a relationship between entrepreneurial competencies and the sustainability of enterprises. Particularly, an entrepreneur's competencies can enhance his or her ability to manage an enterprise (Man, Lau, \& Chan, 2002) in order to maintain firm performance (Gerli, Gubitta, \& Tognazzo, 2011). Mitchelmore and Rowley (2013) contended that entrepreneurial competencies can facilitate enterprise performance, and the economic growth and development.

Nevertheless, several limitations are discovered to slow down the growth of micro-enterprises (Lateh, Hussain, \& Halim, 2017). In Malaysia, human factor is one of the major challenges local micro-enterprises need to overcome (Wahid, Aziz, \& Halim, 2017). Specifically, the influence of entrepreneurial traits and competencies on the firm performance and sustainability remains unexplored (Gerli et al., 2011). Moreover, salient entrepreneurial traits such as locus of control, tolerance of ambiguity, persistence, visionary, and resilience have been under-researched. To address this limitation, this study examined the effect of these entrepreneurial traits on entrepreneurial competencies, enterprise performance, and sustainability of micro-enterprises in Kelantan, Malaysia.

\section{LITERATURE REVIEW}

\section{The Dimensions of Entrepreneurial Traits}

Fundamentally, entrepreneurs with unique characteristics can achieve different organizational success (Beattie, 2016; Gartner, 1990). Entrepreneurial traits can be considered as attitudes, beliefs and behaviors that focuses on opportunities arising from the ability to deal with uncertainty, leading to an attenuated perception of risk and a proactive disposition (Pendergast, 2003). The value creation is dependent on the capabilities of entrepreneurs to perform their roles (Grant, 1991). This indicates the connection between entrepreneurial traits and competencies to achieve certain organizational success metrics (Beattie, 2016). To further illustrate, Gartner (1990) signified that risk taking, locus of control, autonomy, perseverance, commitment, vision, and creativity are characteristics that describe entrepreneurs. Undeniably, locus of control, vision, desire for independence, passion, goal setting, self-drive, and self-efficacy are significant traits of entrepreneurs (Shane et al., 2003). In this case, the present study incorporates locus of control, tolerance of ambiguity, visionary, persistence, and resilience as dimensions of entrepreneurial traits to predict entrepreneurial competencies, enterprise performance and sustainability.

\section{The Resource-based view, Entrepreneurial Traits, and Micro-Enterprise Performance}

Resource-based view (RBV) is one of the prominent theories applied to explain the importance of firm resources on enterprise performance (Barney, 1991; Runyan, Huddleston, \& Swinney, 2006; Wernerfelt, 1984). Firm resources can be both tangible (capital, access to capital, and location) and intangible (knowledge, skills, and reputation) in nature (Runyan et al., 2006). As mentioned by Barney (1991), a resource must be rare, valuable, imperfectly mobile, and non-substitutable to yield 
competitive advantage. In other words, business entities can obtain advantages from unique resources such as managerial skills, organizational skills, information, and knowledge (Barney, 1991; Runyan et al., 2006).

In this study, micro-enterprises rely on the owners' characteristics and skills to sustain (Lerner \& Almor, 2002). The value creation process of micro-enterprises is strongly linked to the ability of entrepreneurs to procure and deploy resources (Barney, 1991; Grant, 1991; Tehseen \& Ramayah, 2015). Low-income entrepreneurs have valuable knowledge, skills, and capabilities that are considered intangible and valuable to create sustainable competitive advantage (Tehseen \& Ramayah, 2015). Undeniably, an individual's traits and competencies are unique and difficult to be imitated by rivals (Gerli et al., 2011; Tehseen \& Ramayah, 2015). Therefore, RBV was applied to assert that microenterprises can survive in uncertain socio-economic environments when the owners possess some unique traits and competencies (locus of control, tolerance of ambiguity, visionary traits, persistence, and resilience) to ensure better enterprise performance and sustainability.

\section{Locus of Control and Entrepreneurial Competencies}

Locus of control is defined as those who believe the consequences of their own behaviour are potentially under personal controls (Lefcourt, 1976). Entrepreneurial competencies refer to a set of skills that represent the capability of an entrepreneur to perform a job (Man, et al., 2002; Mitchelmore \& Rowley, 2013). An individual's competency, personal strength, and positive attitude can be predicted by selfesteem, self-efficacy, positive affectivity, and internal locus of control (Walczak \& Derbis, 2017). Primarily, locus of control captures personal characteristics or subsequent actions that influence outcomes (Shane et al., 2003). For instance, those with external locus of control perceive the result of an event is out of their control, while those with internal locus of control perceive their personal actions are influential on the result of an event directly (Rotter, 1966).

RBV was used to explain the relationship between entrepreneurial competency and locus of control that cultivates specific capabilities in order to generate competitive advantage from unique resources (Barney, 1991; Grant, 1991). Locus of control is a personality trait that determines leadership competencies (Tubbs \& Schulz, 2006). Particularly, internal locus of control is a strong psychological trait associated with entrepreneurial competencies (Mueller \& Thomas, 2001). Some indicators of locus of control are found to have a positive impact on the perceptions of self and collective efficacy (Yorulmaz \& Erdem, 2017). Kallaugher and Mollen (2017) noted that external locus of control negatively affects an individual's ability to improve his or her competencies. Based on the above arguments, the following hypothesis is developed.

Hypothesis 1: Locus of control positively and significantly influences entrepreneurial competencies among micro-entrepreneurs in Kelantan, Malaysia.

\section{Locus of Control and Enterprise Performance}

Enterprise performance is a multidimensional construct that consists of a firm's operational and financial outcomes (Venkatraman \& Ramanujam, 1986), which can be reflected through the owner's personality (Baum \& Locke, 2004; Naffziger, 1995). Basically, locus of control is an individual's beliefs in his or her efforts that influence outcomes (Karasinski \& Anderson, 2017). For example, managers have knowledge, skills, beliefs, and capabilities to facilitate firm performance (Barney, 1991; Grant, 1991; Tehseen \& Ramayah, 2015). Therefore, locus of control is a valuable and unique capability which drives firms to excellence. According to Gupta, Singh, and Singh (2018), locus of control is a personality variable and stressful life events are causally implicated in a variety of unenviable effects on performance. Previous studies confirmed a positive relationship between locus of control and venture performance (Aldrich \& Wiedenmayer, 1993; Baum \& Locke, 2004). To illustrate, the Chief Executive Officer's locus of control can determine organizational performance 
(Boone, Brabander, \& Witteloostuijn, 1996). In addition, locus of control is also found to predict work performance (Chen \& Silverthorne, 2008). Boone and VanWitteloostuijn (2005) indicated that groups with higher average internal locus-of-control scores perform better with low locus-of-control heterogeneity. Based on the above discussion, the following hypothesis is developed.

Hypothesis 2: Locus of control positively and significantly influences micro-enterprise performance in Kelantan, Malaysia.

\section{Tolerance of Ambiguity and Entrepreneurial Competencies}

Tolerance of ambiguity is defined individuals are attracted to ambiguous situations wherein timely information is incomplete to understand a particular situation or future (Mclain, 1993). In general, tolerance of ambiguity arises when entrepreneurs are unable to deal with ambiguity and act in an optimistic manner due to lacks definitive and complete information (Ibrahim \& Soufani, 2002). Interestingly the same tolerance of ambiguity allows entrepreneurs to organize their thoughts and facilitate the development of novel and creative competencies in challenging conditions (Ibrahim \& Soufani, 2002). Individual traits such as extraversion and tolerance for ambiguity stem from individual traits (Niedbala \& Feinberg, 2017). Tolerance of ambiguity, emotional stability, need for achievement, locus of control, risk-taking propensity, and goal setting are determinants of entrepreneurial competencies (Masurel \& Snellenberg, 2017). Wagener, Gorgievski, and Rijsdijk (2010) stated that tolerance of ambiguity enables small business owners to develop competencies in terms of business novelty. Although extreme ambiguity can prevent managers from acquiring competitive advantage, relevant competencies reduce the perception of risks that hinder actions to be taken in uncertain circumstances (Pendergast, 2003; Ibrahim \& Soufani, 2002). Based on the above justification, the following hypothesis is proposed.

Hypothesis 3: Tolerance of ambiguity positively and significantly influences entrepreneurial competencies among micro-entrepreneurs in Kelantan, Malaysia.

\section{Tolerance of Ambiguity and Enterprise Performance}

Ambiguity is associated with perceived risk during decision making (Sitkin \& Pablo, 1992). Tolerance of ambiguity is positively related to work performance across cross-cultural settings (Herman et al., 2010). Entrepreneurs with higher tolerance of ambiguity can be considered as a firm's rare and valuable capability, which is inimitable in nature, to encourage firm performance (Barney, 1991). The absence of certainty has the potential to establish new business entities where both customers and suppliers are new and jobs are undefined in an external environment (Pendergast, 2003). Individuals who are innovative, creative, flexible, risk-taking, and tolerant of uncertainty and ambiguity can help SMEs to achieve competitive advantage (Chen \& Huang, 2007). Powell, Lovallo, and Caringal (2006) found a causal relationship between tolerance of ambiguity and performance. Based on the discussion, this study incorporated tolerance of ambiguity as a salient entrepreneurial trait to predict firm performance, thus the following hypothesis is proposed:

Hypothesis 4: Tolerance of ambiguity positively and significantly influences micro-enterprise performance in Kelantan, Malaysia.

\section{Visionary and Entrepreneurial Competencies}

Visionary is the ability of an organization to establish a long-term vision through any means of inspirational, communicational, ideological, and intellectual expertise (Douglas \& Fredendall, 2004; House \& Howell, 1992). In particular, visionary explains single-minded individual who is committed 
in the pursuit of his or her vision while confronting skeptic naysayers and inadequacy of external resources (Sarasvathy \& Venkataraman, 2011). Drawing upon the RBV, visionary is a form of unique and inimitable resource which instigates entrepreneurial competencies and acquires competitive advantage (Barney, 1991; Grant, 1991). Visionary is formed when competitive behavior, competitive strength, and resource capability profiles are recognized to determine a firm's managerial vision, competencies and capacities, technological and logistic profiles, as well as financial access (Fernald, Solomon, \& Tarabishy, 2005). Both visionary and self-confidence embedded in an individual can strengthen his or her entrepreneurial competencies (Fernald et al., 2005). Thompson (1999) highlighted that visionary can reflect an underlying strategic competency of the organizations. Further, creative entrepreneurial behavior and competencies can be constructed through appropriate visionary leadership trait (Fillis \& Rentschler, 2010). Based on the above discussion, the following hypothesis is developed.

Hypothesis 5: Visionary positively and significantly influences entrepreneurial competencies among micro-entrepreneurs in Kelantan, Malaysia.

\section{Visionary and Enterprise Performance}

Visionary and innovativeness are leadership traits which can enhance performance (Musa et al., 2018). RBV posits that visionary is a firm's rare and valuable resource, which is inimitable in nature (Barney, 1991). Visionary is a significant determinant of entrepreneurial venture growth (Baum, Smith, \& Locke 2001). Baum, Locke, and Kirkpatrick (1998) found a direct and an indirect relationship between visionary attribute, vision content, vision communication, and firm performance among small ventures. Fillis and Rentschler (2010) noted that the integration of visionary, judgment, curiosity, and opportunity recognition enables organizations to achieve competitive advantage. Jing (2017) ascertained that organizations that practice organic and visionary leadership perform better than those employing transactional and classical approach. According to DeLuque et al. (2008), visionary leadership can positively influence employees' effort and firm performance. This kind of leadership is critical to social entrepreneurship engagement (Urban, 2008). It also allows the individuals to develop a networking and connect an inspiring vision to motivate partners, staffs, and volunteers. In particular, entrepreneurs require visionary with strong leadership to develop small firms (Mintzberg, 1990; Onstenk, 2003). Based on the above discussion, the following hypothesis is developed.

Hypothesis 6: Visionarypositively and significantly influences micro-enterprise performance in Kelantan, Malaysia.

\section{Persistence and Entrepreneurial Competencies}

Persistence is defined as the efforts sustained over time (Locke, 2000). In the current study, an entrepreneur requires persistence to run a business with continuous effort despite the impediments, threats, or failures (Cardon et al., 2009). Persistence is a personal characteristic which involves goal-related pursuits despite difficulties, obstacles, fatigue, prolonged frustration or low perceived feasibility. People use knowledge, skills, and behaviours when performing specific activities (Ţuţu \& Constantin, 2012). RBV states that rear, valuable or inimitable resources can facilitate the development of specific capabilities to maintain performance (Barney, 1991; Grant, 1991). Being said that, persistence is considered as a unique and valuable resource to establish successful business. Other characteristics such as creativity, confidence, and initiative can also contribute to successful entrepreneurs (McClelland, 1987). Essentially, persistent behavior reflects higher interest in achievement that improves opportunity recognition (Baum \& Locke, 2004; Cardon et al., 2009). Hayton and Kelley (2006) mentioned that competence building requires tacit knowledge through industrial experience and persistence, creative thinking, coping, and risk-taking to prove a positive 
relationship between competency and persistence. Based on the above arguments, the following hypothesis is developed.

Hypothesis 7: Persistence positively and significantly influences entrepreneurial competencies among micro-entrepreneurs in Kelantan, Malaysia.

\section{Persistence and Enterprise Performance}

Persistence is defined as repeated or different actions taken to overcome obstacles (McClelland, 1987). Undoubtedly, entrepreneurial success requires dogged persistence and determination (Pendergast, 2003). As suggested by the RBV, firms perform differently due to different resources and capabilities although they are in the same industry (Barney, 1991). Entrepreneurship is a journey with skeptic naysayers, limited resources, unexpected bumps, and restricted novel ideas, these predicaments require persistence to overcome (Pendergast, 2003; Sarasvathy \& Venkataraman, 2011). For example, Ţuţu and Constantin (2012) found a strong positive relationship between persistence and performance. Persistence is necessary when there are scarce resources within a diversified corporate environment (Hayton \& Kelley, 2006). Fernald et al. (2005) asserted that persistence is required by entrepreneurs to operate businesses successfully. Besides persistence, they must also possess passion (Baum \& Locke, 2004). To add on, both persistence and perseverance are lubricants of new venture (Mitchelmore \& Rowley, 2013). Kagbu (2018) affirmed that persistence, commitment to work contract, and risktaking are salient characteristics among women entrepreneurs. Based on the arguments, the following hypothesis is developed.

Hypothesis 8: Persistence positively and significantly influences micro-enterprise performance in Kelantan, Malaysia.

\section{Resilience and Entrepreneurial Competencies}

Resilience is the ability to endure tribulation after experiencing hardships or adversities (Tedeschi $\&$ Calhoun, 2004). In uncertain and rapidly-changing circumstances, resiliency is required by entrepreneurs to bounce back from disappointment in order to brush up their competencies (DeFillippi \& Arthur, 1996). As stated in the RBV, resilience is a unique and valuable resource entrepreneurs have to improve (Barney, 1991). As individuals evaluate their current competencies and invest in new competencies to fulfil the latest technological and market trends, resilience is a salient determinant of overall work competencies (DeFillippi \& Arthur, 1996). Steyn and VanStaden (2018) asserted that personal drive and resilience are salient elements of self-management competencies. Santos, Caetano, and Curral (2013) argued that resilience is important for developing entrepreneurial competencies. Based on the above discussion, the following hypothesis is developed.

Hypothesis 9: Resilience positively and significantly influences entrepreneurial competencies among micro-entrepreneurs in Kelantan, Malaysia.

\section{Resilience and Enterprise Performance}

Resilience gains considerable research attention, especially when entrepreneurs failed to run their business (Bullough, Renko, \& Myatt, 2014). To reiterate, RBV concurs that firms perform differently due to different capabilities (Barney, 1991). This implies that resilience is an individual-specific, rear, and inimitable capability for entrepreneurs. Hill and McGowan (1996) stressed that both motivation and resilience can influence management responses and marketing challenges. Bullough et al. (2014) indicated that self-efficacy and entrepreneurial resilience are key factors that encourage the pursuit of entrepreneurial initiatives in challenging situations. Hence, entrepreneurs can develop social, cognitive, 
emotional, and financial resilience for venture launch (Hayward et al., 2010). Peterson et al. (2009) confirmed that psychological traits such as resiliency, optimism, and hope are crucial for improving firm performance. Based on the discussion, the following hypothesis is developed.

Hypothesis 10: Resilience positively and significantly influences micro-enterprise performance in Kelantan, Malaysia.

\section{Entrepreneurial Competencies and Enterprise Performance}

Entrepreneurial competencies maintain firm performance that ensures business success (Ellen, Anantadjaya, \& Saroso, 2014). RBV underpins that entrepreneurial competencies such as knowledge, skills, and abilities are unique and intangible resources which intensify firm performance (Barney, 1991; Grant, 1991; Tehseen \& Ramayah, 2015). For instance, Ţuţu and Constantin (2012) confirmed a strong relationship between performance and competency. According to Gerli et al. (2011), entrepreneurial competency portfolio can improve organizational performance. Besides that, individual competencies can also improve firm performance (Man et al, 2002). Personal relationship, business management, and entrepreneurial and human relations are essential competencies (Mitchelmore \& Rowley, 2013). Moreover, enterprise performance had a positive relationship with education, managerial skills, entrepreneurial characteristics, leaderships, networking and technological capabilities, and entrepreneurial competencies among small firms (Lateh et al., 2017). Furthermore, entrepreneurial competencies are potential determinants of business success in Malaysia (Ahmad et al., 2010). Al-Mamun et al. (2016) proved that entrepreneurial competencies had a positive effect on micro-enterprise performance. Based on the theoretical evidence, the following hypothesis is formulated.

Hypothesis 11: Entrepreneurial competencies positively and significantly influence micro-enterprise performance in Kelantan, Malaysia.

\section{Entrepreneurial Competencies and Enterprise Sustainability}

Enterprise sustainability is defined as the creation of stakeholder-focused business protocols that address various aspects of performance for a short and long term within certain limits imposed by the nature and society (Searcy, 2016). Theoretically, RBV includes entrepreneurial competencies as knowledge, skills, and abilities that create a firm's sustainable competitive advantage (Barney, 1991; Grant, 1991; Tehseen \& Ramayah, 2015). In small firms, core competencies are derived from enterprise sustainability (Moore \& Manring, 2009). Rahman (2016) found that sustaining and expanding operations and survival of micro and small enterprises depended on the skill set of the entrepreneurs. Thus, entrepreneurs should possess relevant skill sets to maintain micro-enterprise sustainability (Lateh et al., 2017). The development of enterprises requires innovative and competent owners, managers, and employees to realize (Mindt \& Rieckmann, 2017). Based on the above discussion, the following hypothesis is formulated.

Hypothesis 12: Entrepreneurial competencies positively and significantly influence micro-enterprise sustainability in Kelantan, Malaysia.

\section{Enterprise Performance and Enterprise Sustainability}

In the present study, enterprise performance was viewed as a multidimensional construct that talks about a firm's operational and financial outcomes (Venkatraman \& Ramanujam, 1986). On the other hand, enterprise sustainability is considered as the creation of stakeholder-focused business systems that address various aspects of performance over a short and long term within the limits imposed 
by the nature and society (Searcy, 2016). Empirically, Goyal and Rahman (2014) found a positive relationship between firm performance and enterprise sustainability performance. Mishra and Suar, (2010) also found a positive relationship between firm performance and corporate sustainability. In contrast, López, Garcia, and Rodriguez (2007) reported a negative relationship between firm performance and corporate sustainability. Nevertheless, Jacobs et al. (2010) revealed an insignificant relationship between firm performance and sustainability. These inconclusive results warranted additional research to be carried out. Hence, the following hypothesis is proposed.

Hypothesis 13: Enterprise performance positively and significantly influences enterprise sustainability among micro-enterprises in Kelantan, Malaysia.

\section{The Mediating Effect of Entrepreneurial Competencies}

This study incorporated locus of control, tolerance of ambiguity, visionary, persistence, and resilience as dimensions of entrepreneurial traits, which were expected to influence micro-enterprise performance through relevant competencies. Hence, logically entrepreneurial competencies were expected to mediate the relationships of these dimensions with enterprise performance, respectively. Drawing on RBV, these dimensions are rear, valuable, and inimitable resources that give rise to specific capabilities, which could be entrepreneurial competency that in turn drive firms to achieve excellent performance (Barney, 1991; Grant, 1991). Peterson et al. (2009) also confirmed the positive effect of psychological traits on firm performance through transformational leadership, suggesting existence of a possible mediator between entrepreneurial traits and enterprise performance. Moreover, Al Mamun, and Fazal, (2018) showed significant mediating effects of entrepreneurial competency on the relationships between several dimensions of entrepreneurial orientation with firm performance. Based on above we argue that examining the indirect effects of entrepreneurial traits' components on enterprise performance through relevant competencies is necessary to enhance our comprehension regarding the interplay between the variables so as to reveal latent and casual relationships between the constructs of interest as well as to offer robust outcomes. Hence, the following hypotheses are proposed:

Hypothesis M1: Entrepreneurial competencies significantly mediate the relationship between locus of control and enterprise performance among micro-enterprises in Kelantan, Malaysia.

Hypothesis M2: Entrepreneurial competencies significantly mediate the relationship between tolerance of ambiguity and enterprise performance among micro-enterprises in Kelantan, Malaysia.

Hypothesis M3: Entrepreneurial competencies significantly mediate the relationship between visionary and enterprise performance among micro-enterprises in Kelantan, Malaysia.

Hypothesis M4: Entrepreneurial competencies significantly mediate the relationship between persistence and enterprise performance among micro-enterprises in Kelantan, Malaysia.

Hypothesis M5: Entrepreneurial competencies significantly mediate the relationship between resilience and enterprise performance among micro-enterprises in Kelantan, Malaysia.

\section{The Mediating Effect of Enterprise Performance}

Given that this study included locus of control, tolerance of ambiguity, visionary, persistence, resilience, and entrepreneurial competencies as salient factors of enterprise performance that determines enterprise sustainability, thus enterprise performance was expected to mediate the relationship between locus of control, tolerance of ambiguity, visionary, persistence, resilience, entrepreneurial competencies, and enterprise sustainability. Theoretically, from the stance of RBV, one can perceive locus of control, tolerance of ambiguity, visionary, persistence, resilience, and entrepreneurial competencies as rare, valuable, and inimitable resources that promote additional 
capabilities (i.e., improved firm performance) amidst firms, thus directing them towards sustainability (Barney, 1991; Grant, 1991). Moreover, cited literature above appears to indicate a significantly positive effect of the identified determinants on enterprise performance (Gupta et al., 2018; Aldrich \& Wiedenmayer, 1993; Baum \& Locke, 2004; Boone et al., 1996; Chen \& Silverthorne, 2008; Chen \& Huang, 2007; Powell et al., 2006; Baum et al., 1998; Fillis \& Rentschler, 2010; DeLuque et al., 2008; Mintzberg, 1990; Onstenk, 2003; Pendergast, 2003; Sarasvathy \& Venkataraman, 2011; Ţuţu \& Constantin, 2012; Fernald et al., 2005; Mitchelmore \& Rowley, 2013; Peterson et al., 2009; Gerli et al., 2011; Man et al, 2002; Lateh et al., 2017; Ahmad et al., 2010; Al-Mamun et al., 2016). At the same time, the existing literature suggests a significantly positive relationship between enterprise performance and sustainability (Goyal \& Rahman, 2014; Mishra \& Suar, 2010), indicating a possible mediating role of enterprise performance. Additionally, Al Mamun et al. (2018) found that enterprise performance has a significant mediating effect on the correlations of entrepreneurial leadership components and enterprise sustainability. Based on above, the following hypotheses are proposed.

Hypothesis M6: Enterprise performance significantly mediates the relationship between locus of control and enterprise sustainability among micro-enterprises in Kelantan, Malaysia.

Hypothesis M7: Enterprise performance significantly mediates the relationship between tolerance of ambiguity and enterprise sustainability among micro-enterprises in Kelantan, Malaysia.

Hypothesis M8: Enterprise performance significantly mediates the relationship between visionary and enterprise sustainability among micro-enterprises in Kelantan, Malaysia.

Hypothesis M9: Enterprise performance significantly mediates the relationship between persistence and enterprise sustainability among micro-enterprises in Kelantan, Malaysia.

Hypothesis M10: Enterprise performance significantly mediates the relationship between resilienceand enterprise sustainability among micro-enterprises in Kelantan, Malaysia.

Hypothesis M11: Enterprise performance significantly mediates the relationship between entrepreneurial competencies and enterprise sustainability among micro-enterprises in Kelantan, Malaysia.

\section{RESEARCH METHODOLOGY}

This study adopted a cross-sectional design and collected quantitative data through structured interview. The sample was micro-entrepreneurs from low-income households in Kelantan, Malaysia. The list of these low-income households was obtained from two organizations. Particularly, 'Majlis Amanah Rakyat' provided a list of 2690 micro-entrepreneurs, whereas 'Majlis Agama Islam dan Adat Istiadat', provided a list of 105 micro-entrepreneurs. With a total of 2795 micro-entrepreneurs, 425 of them were randomly selected from nine districts in Kelantan: Tumpat, Bachok, Jeli, Machang, Gua Musang, Kuala Krai, Pasir Puteh, Pasir Mas, and Tanah Merah. Prior to data collection, potential respondents were contacted and selected to explain the purpose of doing the research and make an appointment with them for interview. The data collection was carried out from September 2017 until November 2017. Only 403 respondents allowed researchers to visit their enterprises and interview them.

\section{Sample Size}

The sample size was determined using G-Power version 3.1. Based on the power of 0.95 (should be more than 0.80 in social and behavioral science research) with an effect size of 0.15 , a sample size of 184 were required to test the model with twelve predictors. To employ PLS-SEM, the minimum sample is 100 (Reinartz, Haenlein \& Henseler, 2009). To avoid any complications arising from a small sample size, this study collected 403 samples from micro-entrepreneurs in Kelantan, Malaysia. 


\section{Research Instrument}

The questionnaire was designed using simple words to allow the respondents to understand the questions easily. Questionnaire items were adapted from earlier studies with minor modifications (see Appendix A). Items that measured locus of control were adopted from Craig, Franklin, and Andrews (1984). To measure tolerance of ambiguity, items were adopted from McLain (1993). Items that measured visionary were adopted from Conger and Kanungo (1994). In terms of persistence, the items were adopted from Duckworth et al. (2007). To measure resilience, items were adopted from Smith et al. (2008). Items that measured entrepreneurial competencies were adopted from Man et al. (2008), while those measured enterprise performance were adopted from Morgan and Strong (2003). Lastly, items that measured enterprise sustainability were adopted from Raymond et al. (2013) and Gualandris et al. (2014). A seven-point Likert scale (from "1-Strongly disagree" to "7-Strongly agree") was used to respond to entrepreneurial competency. Similarly, a seven-point Likert scale (from "1-Very poor" to "7-Very good") was employed to respond to micro-enterprise performance and sustainability. A five-point Likert scale (from "1-Strongly disagree" to "5-Strongly agree") was used to respond to all independent variables.

\section{Common Method Variance (CMV)}

To minimize common method variance (CMV), this study 'informed the respondent that the responses will be evaluated anonymously and there are no right or wrong answers' (Podsakoff, et al., 2003). As recommended by Podsakoff, et al. (2003), this study adopted a five-point Likert scale for independent variables and a seven-point Likert scale for dependent variables. To identify CMV, Harman's (1976) one-factor test was employed to extract one fixed factor from all constructs to explain the variance less than 50 percent. The analysis showed that one component explained 26.34 percent of the variance. CMV can be detected when the correlation between the constructs is higher than 0.9 (Bagozzi et al., 1991). The highest correlation between entrepreneurial competency and enterprise performance was 0.543 , which indicates a lack of CMV.

\section{Multivariate Normality}

Though the PLS method does not require a multivariate normal data distribution, Peng and Lai (2012) recommended not making generalized statements regarding the ability of PLS to estimate a model, which may violate the multivariate normality assumption. Hence, this study used the Web Power online tool to test multivariate normality. Web Power calculated Mardia's multivariate skewness and kurtosis coefficients. As a result, the $p$-value was lower than 0.05 and confirmed the existence of multivariate non-normality.

\section{Data Analysis Method}

Partial least squares-structural equation modeling (PLS-SEM) is a causal modeling approach which explains the variance of the latent constructs (Hair, Ringle, \& Sarstedt, 2011). PLS was developed by Wold (1975) for studies where data could not meet the limiting rules of covariance-based SEM techniques. Moreover in PLS, a construct is perceived as a formative construct in case the concerned items causes the latent variable, where the items are not expected to be correlated (Chin, 2010). PLS is also able to estimate a complex model that comprises of a large number of items or constructs. Furthermore, if the data of a study does not meet the normality criteria, PLS can still effectively be used for a larger number of indicators (Chin, 2010). As this study is exploratory nature with non-normality issue that comprehending a complex model comprising large number of constructs, variance-based PLS-SEM was employed. The analysis was reported according to Hair, Ringle and Sarstedt (2013). The analysis included indicator reliability, internal consistency reliability, convergent validity, discriminant validity, Average Variance Extracted (AVE), effect size, path coefficient estimates, and predictive relevance. 


\section{RESULTS AND FINDINGS}

\section{Demographic Characteristics}

Of 403 respondents, 51.6\% were males and the rest were females. Most respondents (79.9\%) were married. $58.1 \%$ of them received secondary school education. However, most respondents $(71 \%)$ did not have business experience. Of 117 respondents, 54 of them had one year's experience, 24 of them had two years' experience, 15 of them had four years' experience, 14 of them had more than five years' experience, and 10 of them had three years' experience. Besides, $44.9 \%$ of the respondents had at least one full-time employee, $29.5 \%$ of them had two full-time employees, $19.1 \%$ of them had more than four full-time employees, and $6.5 \%$ of them had three full-time employees. In terms of firm age, 136 of the respondents reported that their firms aged between 6 to 10 years, 129 of them reported their firms aged between 1 to 5 years, while 16 of them reported their firms aged less than a year.

\section{Reliability and Validity}

Table 2 presents the descriptive statistics and the reliability of the items. The mean and standard deviation values of all the variables are summarized in Table 2 . To achieve a sturdy research, reliable and valid items are needed. The first criterion is internal consistency reliability. Basically, Cronbach's alpha was used as a conservative measure of internal consistency reliability. The analysis showed that all the variables had a Cronbach's alpha value of more than 0.7 , indicating that all items were reliable. According to Hair et al. (2013), it is appropriate to apply a different measure of internal consistency reliability, which is also known as "composite reliability." The threshold value for composite reliability is 0.7 (Hair et al., 2011). As shown in Table 2, the composite reliability value for all the variables was higher than 0.8 , indicating strong reliability. Moreover, the Dillon-Goldstein rho values for all indicators were higher than 0.7 , which confirmed the reliability of the items.

To achieve convergent validity, AVE value should be higher than 0.50 . As shown in Table 2, the AVE value for all the variables was higher than 0.50 , indicating acceptable convergent validity. This study also obtained variance inflation factors (VIF) to identify the multicollinearity. Since the VIF value for all the variables was below 3.3, multicollinearity was not a serious issue (Diamantopoulos and Siguaw, 2006). In Table 3, the loading and cross-loading values showed that nearly all the indicator loadings were higher than 0.7. As suggested by Chin (1998), items with standardized loadings lower than 0.7 were kept for further analysis, but those with loadings higher than 0.5 should be retained. Therefore, all the indicators' loadings were higher than the total cross-loadings, which confirmed discriminant validity. Based on the Fornell-Larcker criterion as observed in Table 4, the AVE for each indicator should be greater than the variable's highest squared correlation with another. The result reflect that all the variables fulfilled this criterion. Besides, the Heterotrait-Monotrait Ratio (HTMT) in Table 4 estimates the correlation between variables, paralleling the disattenuated construct score. Based on the threshold value of 0.9 , there was no evidence of insufficient discriminant validity.

\section{Path Analysis}

In Table 5, the coefficient value for the effect of locus of control on entrepreneurial competencies (Hypothesis 1 ) was 0.228 with the $p$-value of 0.000 . This indicated that locus of control had a positive effect on entrepreneurial competencies. However, the $f^{2}$ value of 0.048 indicated that locus of control had a minimal effect on entrepreneurial competencies. Besides that, the coefficient value for the effect of locus of control on enterprise performance (Hypothesis 2) was 0.137 with the $p$-value of 0.015 . This indicated that locus of control had a positive effect on enterprise performance. The $f^{2}$ value of 0.018 noted that locus of control had a minimal effect on micro-enterprise performance.

In addition, the coefficient value for tolerance of ambiguity showed an insignificant ( $p$-value $=0.443$ ) effect on entrepreneurial competencies (Hypothesis 3 ). The $f^{2}$ value of 0.002 indicated a nearly zero effect of tolerance of ambiguity on entrepreneurial competencies. Besides that, the path coefficient value for tolerance of ambiguity on enterprise performance (Hypothesis 4) was 0.021 with 
Table 1. Profile of the Respondents

\begin{tabular}{|c|c|c|c|c|c|}
\hline & $\mathbf{N}$ & $\%$ & & $\mathbf{N}$ & $\%$ \\
\hline Gender & & & Education & & \\
\hline Male & 208 & 51.6 & Never attended school & 5 & 1.2 \\
\hline Female & 195 & 48.4 & Primary School & 22 & 5.5 \\
\hline \multirow[t]{2}{*}{ Total } & 403 & 100.0 & Secondary School & 234 & 58.1 \\
\hline & & & STPM/Diploma & 80 & 19.9 \\
\hline Age & & & Undergraduate Degree & 41 & 10.2 \\
\hline 20 years old- 30 years old & 68 & 16.9 & Masters Degree & 3 & 0.7 \\
\hline 31 years old- 40 years old & 119 & 29.5 & Others & 18 & 4.5 \\
\hline 41 years old- 50 years old & 118 & 29.3 & Total & 403 & 100.0 \\
\hline 51 years old- 60 years old & 78 & 19.4 & & & \\
\hline 61 years old and above & 20 & 4.9 & Previous Business Experience & & \\
\hline \multirow[t]{2}{*}{ Total } & 403 & 100.0 & Yes & 117 & 29.0 \\
\hline & & & No & 286 & 71.0 \\
\hline Marital Status & & & Total & 403 & 100.0 \\
\hline Single & 53 & 13.2 & & & \\
\hline Married & 322 & 79.9 & \multicolumn{2}{|l|}{ Years of Business Experience } & \\
\hline Divorced & 13 & 3.2 & No Experience & 286 & 71.0 \\
\hline Widowed & 15 & 3.7 & One year & 54 & 13.4 \\
\hline \multirow[t]{2}{*}{ Total } & 403 & 100.0 & Two tears & 24 & 6.0 \\
\hline & & & Three Years & 10 & 2.5 \\
\hline Age of the Firm & & & Four Years & 15 & 3.7 \\
\hline Less 1year & 16 & 4.0 & Five years and Above & 14 & 3.5 \\
\hline 1-5Years & 129 & 32.0 & Total & 403 & 100.0 \\
\hline 6-10 Years & 136 & 33.7 & & & \\
\hline 11-15 Years & 57 & 14.1 & \multicolumn{2}{|l|}{ Number of Full-Time Employees } & \\
\hline 16-20 Years & 34 & 8.4 & One Employee & 181 & 44.9 \\
\hline More than 20years & 31 & 7.7 & Two Employees & 119 & 29.5 \\
\hline \multirow[t]{3}{*}{ Total } & 403 & 100.0 & Three Employees & 26 & 6.5 \\
\hline & & & Four Employees and above & 77 & 19.1 \\
\hline & & & Total & 403 & 100.0 \\
\hline
\end{tabular}

Source: Author(s) own compilation

the $p$-value of 0.673 . This indicated that tolerance of ambiguity did not have a significant effect on enterprise performance. The $f^{2}$ value of 0.000 indicated a nearly zero effect of tolerance of ambiguity on enterprise performance.

Furthermore, the coefficient for visionary showed a positive and significant ( $p$-value of $0.000<$ 0.05 ) effect on entrepreneurial competencies (Hypothesis 5) with the $f^{2}$ value of 0.085 . This indicated a minimal effect size of visionary on entrepreneurial competencies. To add, the path coefficient value for the effect of visionary on enterprise performance (Hypothesis 6) was 0.134 with the $p$-value of 
Table 2. Reliability and Validity

\begin{tabular}{|l|l|l|l|l|l|l|l|l|}
\hline \multicolumn{1}{|c|}{ Variables } & Items & Mean & \multicolumn{1}{|c|}{ SD } & CA & DG rho & CR & AVE & VIF \\
\hline Locus of Control & 4 & 4.114 & 0.495 & 0.743 & 0.743 & 0.838 & 0.565 & 1.649 \\
\hline Tolerance of Ambiguity & 5 & 3.631 & 0.844 & 0.859 & 0.918 & 0.883 & 0.606 & 1.471 \\
\hline Visionary & 6 & 4.043 & 0.457 & 0.814 & 0.819 & 0.866 & 0.520 & 1.957 \\
\hline Persistence & 4 & 3.951 & 0.651 & 0.786 & 0.890 & 0.852 & 0.598 & 1.335 \\
\hline Resilience & 6 & 4.117 & 0.559 & 0.860 & 0.953 & 0.887 & 0.569 & 1.217 \\
\hline Entrepreneurial Competency & 5 & 5.854 & 0.660 & 0.809 & 0.818 & 0.868 & 0.568 & 1.447 \\
\hline Enterprise Performance & 5 & 5.857 & 0.739 & 0.868 & 0.875 & 0.904 & 0.654 & 1.443 \\
\hline Enterprise Sustainability & 5 & 5.562 & 0.981 & 0.812 & 0.840 & 0.863 & 0.559 & - \\
\hline
\end{tabular}

Note: Standard Deviation (SD); Cronbach's Alpha (CA); Dillon-Goldstein's rho (DG rho); Composite Reliability (CR); Average Variance Extracted (AVE); Variance Inflation Factors (VIF)

Source: Author(s) own compilation

0.033. This indicated that visionary had a positive effect on micro-enterprise performance. However, the $f^{2}$ value of 0.014 signified a low effect size of visionary on enterprise performance.

Apart from that, the coefficient value for persistence showed an insignificant ( $p$-value $=0.169$ ) effect on entrepreneurial competencies (Hypothesis 7). The $f^{2}$ value of 0.006 indicated a very low effect size of persistence on entrepreneurial competencies. Similarly, the coefficient for persistence had a positive $(\beta=0.018)$ and insignificant $(p$-value $=0.720)$ effect on enterprise performance (Hypothesis 8 ). Nonetheless, the $f^{2}$ value of 0.000 indicated a nearly zero effect size of persistence on micro-enterprise performance.

Moreover, the coefficient value for resilience showed a positive $(\beta=0.104)$ and insignificant $(p$-value $=0.052)$ on entrepreneurial competencies (Hypothesis 9$)$. The $f^{2}$ value of 0.013 indicated a small effect size of resilience on entrepreneurial competencies. Besides, the coefficient for resilience showed a positive $(\beta=0.076)$ and insignificant ( $p$-value $=0.199)$ effect on enterprise performance (Hypothesis 10). The $f^{2}$ value of 0.008 indicated a very low effect size of resilience on micro-enterprise performance.

Finally, the coefficient value for entrepreneurial competencies showed a positive $(\beta=0.391)$ and significant ( $p$-value of $0.000<0.05$ ) effect on micro-enterprise performance (Hypothesis 11$)$. The $f^{2}$ value of 0.167 indicated a moderate effect of entrepreneurial competencies on enterprise performance. In addition, the coefficient for entrepreneurial competencies on enterprise sustainability (Hypothesis 12) was 0.371 with the $p$-value of 0.000 . This indicated that entrepreneurial competencies had a positive effect on micro-enterprise sustainability. Then, the $f^{2}$ value of 0.154 showed a moderate effect of entrepreneurial competencies on enterprise sustainability. Similarly, the coefficients for enterprise performance showed a positive $(\beta=0.331)$ and significant $(p$-value of $0.000<0.05$ ) effect on microenterprise sustainability (Hypothesis 13 ). The $f^{2}$ value of 0.123 signified a small to moderate effect of enterprise performance on enterprise sustainability.

In this case, 30.9 percent of the variation in entrepreneurial competencies was explained by locus of control, tolerance of ambiguity, visionary, persistence, and resilience. Specifically, the $R^{2}$ for enterprise performance was 0.369 . This indicated that 36.9 percent of the variation in enterprise performance was explained by locus of control, tolerance of ambiguity, visionary, persistence, resilience, and entrepreneurial competencies. To add, the $R^{2}$ for enterprise sustainability was 0.383 , indicating that 38.3 percent of the variation in enterprise sustainability was explained by entrepreneurial competencies and enterprise performance. The $Q^{2}$ value of 0.161 showed that locus of control, tolerance of ambiguity, visionary, persistence, and resilience had a lower predictive relevance for entrepreneurial competencies. Conversely, the $Q^{2}$ value of 0.216 meant that locus of control, tolerance 
Table 3. Loadings and Cross-Loadings

\begin{tabular}{|c|c|c|c|c|c|c|c|c|}
\hline Item Code & LC & TA & VI & PE & $\mathbf{R E}$ & EC & EP & ES \\
\hline LC - Item 1 & 0.753 & 0.276 & 0.482 & 0.225 & 0.272 & 0.304 & 0.327 & 0.215 \\
\hline LC - Item 2 & 0.729 & 0.229 & 0.314 & 0.196 & 0.196 & 0.371 & 0.349 & 0.189 \\
\hline LC - Item 3 & 0.770 & 0.316 & 0.506 & 0.316 & 0.325 & 0.355 & 0.320 & 0.296 \\
\hline LC - Item 4 & 0.753 & 0.266 & 0.446 & 0.249 & 0.201 & 0.343 & 0.298 & 0.347 \\
\hline TA - Item 1 & 0.143 & 0.604 & 0.342 & 0.194 & 0.183 & -0.036 & 0.095 & 0.210 \\
\hline TA - Item 2 & 0.326 & 0.855 & 0.430 & 0.369 & 0.211 & 0.269 & 0.228 & 0.354 \\
\hline TA - Item 3 & 0.338 & 0.867 & 0.371 & 0.420 & 0.178 & 0.266 & 0.255 & 0.253 \\
\hline TA - Item 4 & 0.198 & 0.725 & 0.367 & 0.277 & 0.195 & 0.047 & 0.101 & 0.206 \\
\hline TA - Item 5 & 0.270 & 0.811 & 0.411 & 0.358 & 0.252 & 0.145 & 0.206 & 0.264 \\
\hline VI - Item 1 & 0.433 & 0.318 & 0.665 & 0.217 & 0.291 & 0.285 & 0.317 & 0.322 \\
\hline VI - Item 2 & 0.458 & 0.328 & 0.760 & 0.319 & 0.311 & 0.389 & 0.372 & 0.391 \\
\hline VI - Item 3 & 0.343 & 0.329 & 0.642 & 0.280 & 0.191 & 0.330 & 0.289 & 0.323 \\
\hline VI - Item 4 & 0.465 & 0.389 & 0.767 & 0.216 & 0.232 & 0.372 & 0.331 & 0.375 \\
\hline VI - Item 5 & 0.364 & 0.345 & 0.771 & 0.214 & 0.232 & 0.355 & 0.329 & 0.417 \\
\hline VI - Item 6 & 0.432 & 0.366 & 0.713 & 0.331 & 0.331 & 0.422 & 0.320 & 0.353 \\
\hline PE - Item 1 & 0.189 & 0.314 & 0.260 & 0.696 & 0.156 & 0.126 & 0.114 & 0.142 \\
\hline PE - Item 2 & 0.224 & 0.360 & 0.227 & 0.570 & 0.191 & 0.100 & 0.106 & 0.167 \\
\hline PE - Item 3 & 0.281 & 0.394 & 0.316 & 0.880 & 0.161 & 0.258 & 0.236 & 0.223 \\
\hline PE - Item 4 & 0.305 & 0.355 & 0.327 & 0.899 & 0.258 & 0.285 & 0.245 & 0.212 \\
\hline RE - Item 1 & 0.244 & 0.164 & 0.241 & 0.125 & 0.711 & 0.233 & 0.218 & 0.218 \\
\hline RE - Item 2 & 0.104 & 0.128 & 0.194 & 0.198 & 0.656 & 0.152 & 0.088 & 0.193 \\
\hline RE - Item 3 & 0.162 & 0.177 & 0.233 & 0.179 & 0.713 & 0.138 & 0.079 & 0.214 \\
\hline RE - Item 4 & 0.246 & 0.256 & 0.258 & 0.192 & 0.819 & 0.206 & 0.206 & 0.222 \\
\hline RE - Item 5 & 0.210 & 0.228 & 0.276 & 0.184 & 0.804 & 0.113 & 0.127 & 0.194 \\
\hline RE - Item 6 & 0.352 & 0.184 & 0.369 & 0.224 & 0.807 & 0.347 & 0.377 & 0.249 \\
\hline EC - Item 1 & 0.362 & 0.113 & 0.338 & 0.186 & 0.152 & 0.778 & 0.453 & 0.366 \\
\hline EC - Item 2 & 0.309 & 0.160 & 0.349 & 0.189 & 0.176 & 0.789 & 0.407 & 0.419 \\
\hline EC - Item 3 & 0.337 & 0.217 & 0.356 & 0.178 & 0.275 & 0.720 & 0.344 & 0.361 \\
\hline EC - Item 4 & 0.318 & 0.253 & 0.358 & 0.211 & 0.262 & 0.676 & 0.358 & 0.422 \\
\hline EC - Item 5 & 0.393 & 0.207 & 0.468 & 0.260 & 0.283 & 0.800 & 0.502 & 0.500 \\
\hline $\mathrm{EP}$ - Item 1 & 0.360 & 0.157 & 0.423 & 0.205 & 0.190 & 0.489 & 0.818 & 0.441 \\
\hline $\mathrm{EP}$ - Item 2 & 0.402 & 0.222 & 0.417 & 0.168 & 0.206 & 0.468 & 0.799 & 0.457 \\
\hline $\mathrm{EP}$ - Item 3 & 0.257 & 0.188 & 0.263 & 0.171 & 0.203 & 0.381 & 0.783 & 0.308 \\
\hline EP - Item 4 & 0.331 & 0.206 & 0.279 & 0.206 & 0.291 & 0.410 & 0.809 & 0.434 \\
\hline $\mathrm{EP}$ - Item 5 & 0.371 & 0.267 & 0.416 & 0.242 & 0.315 & 0.473 & 0.835 & 0.494 \\
\hline ES - Item 1 & 0.177 & 0.236 & 0.348 & 0.151 & 0.181 & 0.342 & 0.301 & 0.784 \\
\hline
\end{tabular}


Table 3. Continued

\begin{tabular}{|l|l|l|l|l|l|l|l|l|}
\hline \multicolumn{1}{|c|}{ Item Code } & \multicolumn{1}{|c|}{ LC } & TA & VI & \multicolumn{1}{c|}{ PE } & \multicolumn{1}{c|}{ RE } & \multicolumn{1}{c|}{ EC } & \multicolumn{1}{c|}{ EP } & ES \\
\hline ES - Item 2 & 0.163 & 0.204 & 0.348 & 0.173 & 0.168 & 0.319 & 0.324 & 0.764 \\
\hline ES - Item 3 & 0.214 & 0.232 & 0.383 & 0.055 & 0.151 & 0.232 & 0.281 & 0.615 \\
\hline ES - Item 4 & 0.295 & 0.262 & 0.380 & 0.213 & 0.236 & 0.503 & 0.467 & 0.769 \\
\hline ES - Item 5 & 0.366 & 0.308 & 0.426 & 0.247 & 0.296 & 0.539 & 0.522 & 0.791 \\
\hline
\end{tabular}

Note:(a) Locus of Control (LC); Tolerance of Ambiguity (TA); Visionary (VI); Persistence (PE); Resilience (RE); Entrepreneurial Competencies (EC); Enterprise Performance (EP); Enterprise Sustainability (ES)

(b) The Italic values in the matrix above are the item loadings and others are cross-loadings

Source: Author(s) own compilation

\section{Table 4. Fornell-Larcker Criterion and HTMT}

\begin{tabular}{|c|c|c|c|c|c|c|c|c|}
\hline Test/Variables & $\mathbf{L C}$ & TA & VI & PE & $\mathbf{R E}$ & EC & EP & ES \\
\hline Fornell-Larcker Criterion & 0.751 & & & & & & & \\
\hline Locus of Control & 0.361 & 0.778 & & & & & & \\
\hline Tolerance of Ambiguity & 0.578 & 0.480 & 0.721 & & & & & \\
\hline Visionary & 0.328 & 0.445 & 0.367 & 0.773 & & & & \\
\hline Persistence & 0.330 & 0.250 & 0.369 & 0.245 & 0.754 & & & \\
\hline Resilience & 0.459 & 0.251 & 0.501 & 0.275 & 0.306 & 0.754 & & \\
\hline Ent. Competencies & 0.432 & 0.260 & 0.453 & 0.247 & 0.300 & 0.554 & 0.809 & \\
\hline Enterprise Performance & 0.346 & 0.340 & 0.505 & 0.243 & 0.291 & 0.554 & 0.536 & 0.747 \\
\hline Enterprise Sustainability & 0.751 & & & & & & & \\
\hline \multicolumn{9}{|c|}{ Heterotrait-Monotrait Ratio (HTMT) } \\
\hline Locus of Control & - & & & & & & & \\
\hline Tolerance of Ambiguity & 0.402 & - & & & & & & \\
\hline Visionary & 0.747 & 0.576 & - & & & & & \\
\hline Persistence & 0.421 & 0.521 & 0.450 & - & & & & \\
\hline Resilience & 0.359 & 0.308 & 0.405 & 0.299 & - & & & \\
\hline Ent. Competencies & 0.586 & 0.240 & 0.608 & 0.315 & 0.309 & - & & \\
\hline Enterprise Performance & 0.528 & 0.253 & 0.528 & 0.269 & 0.273 & 0.647 & - & \\
\hline Enterprise Sustainability & 0.417 & 0.396 & 0.612 & 0.279 & 0.320 & 0.626 & 0.585 & - \\
\hline
\end{tabular}

Note: Locus of Control (LC); Tolerance of Ambiguity (TA); Visionary (VI); Persistence (PE); Resilience (RE); Entrepreneurial Competencies (EC); Enterprise Performance (EP); Enterprise Sustainability (ES)

Source: Author(s) own compilation

of ambiguity, visionary, persistence, resilience, and entrepreneurial competencies had a moderate predictive relevance for enterprise performance. Last but not least, the $Q^{2}$ value of 0.180 meant that both entrepreneurial competencies and enterprise performance had a low to moderate predictive relevance for enterprise sustainability. 
Table 5. Path Analysis

\begin{tabular}{|c|c|c|c|c|c|c|c|}
\hline Нуро & & Coefficient & Sig. & Decision & $r^{2}$ & $f^{2}$ & $\mathbf{Q}^{2}$ \\
\hline $\mathrm{H}_{1}$ & $\mathrm{LC} \rightarrow \mathrm{EC}$ & 0.228 & 0.000 & Accept & & 0.048 & \\
\hline $\mathrm{H}_{3}$ & $\mathrm{TA} \rightarrow \mathrm{EC}$ & -0.047 & 0.443 & Reject & & 0.002 & \\
\hline $\mathrm{H}_{5}$ & $\mathrm{VI} \rightarrow \mathrm{EC}$ & 0.326 & 0.000 & Accept & 0.309 & 0.085 & 0.161 \\
\hline $\mathrm{H}_{7}$ & $\mathrm{PE} \rightarrow \mathrm{EC}$ & 0.076 & 0.169 & Reject & & 0.006 & \\
\hline $\mathrm{H}_{9}$ & $\mathrm{RE} \rightarrow \mathrm{EC}$ & 0.104 & 0.052 & Reject & & 0.013 & \\
\hline $\mathrm{H}_{2}$ & $\mathrm{LC} \rightarrow \mathrm{EP}$ & 0.137 & 0.015 & Accept & & 0.018 & \\
\hline $\mathrm{H}_{4}$ & $\mathrm{TA} \rightarrow \mathrm{EP}$ & 0.021 & 0.673 & Reject & & 0.000 & \\
\hline $\mathrm{H}_{6}$ & $\mathrm{VI} \rightarrow \mathrm{EP}$ & 0.134 & 0.033 & Accept & 0.369 & 0.014 & 0.216 \\
\hline $\mathrm{H}_{8}$ & $\mathrm{PE} \rightarrow \mathrm{EP}$ & 0.018 & 0.720 & Reject & & 0.000 & \\
\hline $\mathrm{H}_{10}$ & $\mathrm{RE} \rightarrow \mathrm{EP}$ & 0.076 & 0.199 & Reject & & 0.008 & \\
\hline $\mathrm{H}_{11}$ & $\mathrm{EC} \rightarrow \mathrm{EP}$ & 0.391 & 0.000 & Accept & & 0.167 & \\
\hline $\mathrm{H}_{12}$ & $\mathrm{EC} \rightarrow \mathrm{ES}$ & 0.371 & 0.000 & Accept & \multirow[t]{2}{*}{0.383} & 0.154 & \multirow[t]{2}{*}{0.180} \\
\hline $\mathrm{H}_{13}$ & $\mathrm{EP} \rightarrow \mathrm{ES}$ & 0.331 & 0.000 & Accept & & 0.123 & \\
\hline
\end{tabular}

Note: Locus of Control (LC); Tolerance of Ambiguity (TA); Visionary (VI); Persistence (PE); Resilience (RE); Entrepreneurial Competencies (EC); Enterprise Performance (EP); Enterprise Sustainability (ES)

Source: Author(s) own compilation

\section{Mediating Effects}

Regarding the mediating effects of entrepreneurial competencies and enterprise performance, this study presented the indirect effect coefficients, confidence intervals, and $p$-values (see Table 6). The result revealed both locus of control and visionary had a positive and indirect effect on enterprise performance ( $p$-values $<0.05)$. This result confirmed a mediating effect of entrepreneurial competencies on the

Table 6. Mediating Effects

\begin{tabular}{|l|l|l|l|l|l|l|}
\hline \multicolumn{2}{|c|}{ Path } & \multicolumn{1}{c|}{ Beta } & \multicolumn{1}{c|}{ CI-Min } & \multicolumn{1}{c|}{ CI-Max } & \multicolumn{1}{c|}{ Sig. } & \multicolumn{1}{c|}{ Decision } \\
\hline $\mathrm{H}_{\mathrm{M} 1}$ & $\mathrm{LC} \rightarrow \mathrm{EC} \rightarrow \mathrm{EP}$ & 0.089 & 0.040 & 0.142 & 0.001 & Mediation \\
\hline $\mathrm{H}_{\mathrm{M} 2}$ & $\mathrm{TA} \rightarrow \mathrm{EC} \rightarrow \mathrm{EP}$ & -0.018 & -0.068 & 0.030 & 0.447 & No Mediation \\
\hline $\mathrm{H}_{\mathrm{M} 3}$ & $\mathrm{VI} \rightarrow \mathrm{EC} \rightarrow \mathrm{EP}$ & 0.127 & 0.061 & 0.205 & 0.001 & Mediation \\
\hline $\mathrm{H}_{\mathrm{M} 4}$ & $\mathrm{PE} \rightarrow \mathrm{EC} \rightarrow \mathrm{EP}$ & 0.030 & -0.012 & 0.071 & 0.173 & No Mediation \\
\hline $\mathrm{H}_{\mathrm{M} 5}$ & $\mathrm{RE} \rightarrow \mathrm{EC} \rightarrow \mathrm{EP}$ & 0.041 & 0.002 & 0.093 & 0.076 & No Mediation \\
\hline $\mathrm{H}_{\mathrm{M} 6}$ & $\mathrm{LC} \rightarrow \mathrm{EP} \rightarrow \mathrm{ES}$ & 0.159 & 0.093 & 0.231 & 0.000 & Mediation \\
\hline $\mathrm{H}_{\mathrm{M} 7}$ & $\mathrm{TA} \rightarrow \mathrm{EP} \rightarrow \mathrm{ES}$ & -0.017 & -0.079 & 0.051 & 0.604 & No Mediation \\
\hline $\mathrm{H}_{\mathrm{M} 8}$ & $\mathrm{VI} \rightarrow \mathrm{EP} \rightarrow \mathrm{ES}$ & 0.207 & 0.100 & 0.318 & 0.000 & Mediation \\
\hline $\mathrm{H}_{\mathrm{M} 9}$ & $\mathrm{PE} \rightarrow \mathrm{EP} \rightarrow \mathrm{ES}$ & 0.044 & -0.018 & 0.115 & 0.206 & No Mediation \\
\hline $\mathrm{H}_{\mathrm{M} 10}$ & $\mathrm{RE} \rightarrow \mathrm{EP} \rightarrow \mathrm{ES}$ & 0.077 & 0.029 & 0.135 & 0.006 & Mediation \\
\hline $\mathrm{H}_{\mathrm{M} 11}$ & $\mathrm{EC} \rightarrow \mathrm{EP} \rightarrow \mathrm{ES}$ & 0.129 & 0.074 & 0.205 & 0.000 & Mediation \\
\hline
\end{tabular}

Note: Locus of Control (LC); Tolerance of Ambiguity (TA); Visionary (VI); Persistence (PE); Resilience (RE); Entrepreneurial Competencies (EC); Enterprise Performance (EP); Enterprise Sustainability (ES)

Source: Author(s) own compilation 
relationship between locus of control and visionary, and enterprise performance. Hence, $\mathrm{H}_{\mathrm{M} 1}$ andH $\mathrm{H}_{\mathrm{M} 3}$ were supported, but $\mathrm{H}_{\mathrm{M} 2}, \mathrm{H}_{\mathrm{M} 4}$, and $\mathrm{H}_{\mathrm{M} 5}$ were not supported. As a result, entrepreneurial competencies did not mediate the relationship between tolerance of ambiguity, persistence and resilience, and enterprise performance. Moreover, there was a positive and indirect effect of locus of control, visionary, resilience, and entrepreneurial competencies found on enterprise sustainability. Thus, $\mathrm{H}_{\mathrm{M} 6}, \mathrm{H}_{\mathrm{M} 8}, \mathrm{H}_{\mathrm{M} 10}$, and $\mathrm{H}_{\mathrm{M} 11}$ were supported. Nevertheless, enterprise performance did not mediate the relationship between tolerance of ambiguity and persistence, and enterprise sustainability. As a consequence, $\mathrm{H}_{\mathrm{M} 7}$ and $\mathrm{H}_{\mathrm{M} 9}$ were not supported.

\section{DISCUSSION AND IMPLICATION}

This study examined the effect of entrepreneurial traits (locus of control, tolerance of ambiguity, visionary, persistence, and resilience) on entrepreneurial competencies, enterprise performance, and sustainability. The finding revealed that locus of control had a positive effect on entrepreneurial competencies, which was consistent with Tubbs and Schulz's (2006) study. Their study highlighted that locus of control could determine both leadership and entrepreneurial competencies. Concurrently, the finding also revealed a positive effect of locus of control on enterprise performance, which was in line with several previous studies (Aldrich \& Wiedenmayer, 1993; Baum \& Locke, 2004; Boone et al. 1996).

Unexpectedly, this study found an insignificant effect of tolerance of ambiguity on entrepreneurial competencies. This finding implied that extreme ambiguity can minimize competencies required for achieving competitive advantage in uncertain environments (Pendergast, 2003; Ibrahim \& Soufani, 2002). Interestingly, tolerance of ambiguity had a positive but insignificant effect on micro-enterprise performance. This finding supported Powell et al.'s (2006) study. Besides that, the result showed a positive effect of visionary on entrepreneurial competencies, which was consistent with few studies (Fernald et al., 2005; Thompson, 1999). These studies suggested that visionary was fundamental to the development of firm competencies. The result also confirmed a positive effect of visionary trait on micro-enterprise performance, which was in line with Fillis and Rentschler (2010). This study ascertained that firms with visionary were able to gain competitive advantage.

On top of that, the finding revealed a positive but statistically insignificant effect of persistence on entrepreneurial competencies and enterprise performance. A possible explanation was low-income households with perseverance are likely to succeed (McClelland, 1987), but not among microenterprises in Kelantan. Similarly, resilience had a positive but statistically not significant effect on entrepreneurial competencies and micro-enterprise performance.

Furthermore, this study found a positive effect of entrepreneurial competencies on microenterprise performance. RBV and prior studies confirmed that entrepreneurial competencies are valuable and intangible capabilities that ensure excellent organizational performance (Al-Mamun et al., 2016; Ahmad et al., 2010; Barney, 1991; Gerli et al., 2011; Grant, 1991; Mitchelmore \& Rowley, 2013; Tehseen \& Ramayah, 2015). Similarly, entrepreneurial competencies had a positive effect on micro-enterprise sustainability performance, which was in agreement with several studies (Mindt \& Rieckmann, 2017; Moore \& Manring, 2009; Rahman, 2016). Subsequently, enterprise performance had a positive effect on micro-enterprise sustainability (Mishra \& Suar, 2010; Goyal \& Rahman, 2014).

Last but not least, the finding showed a mediating effect of entrepreneurial competencies on the relationship between locus of control and visionary, and enterprise performance. Reverting to RBV and existing studies, this finding indicated that locus of control and visionary are unique and valuable resources that indirectly affect firm performance through entrepreneurial competency (Barney, 1991; Grant, 1991; Peterson et al., 2009). Furthermore, locus of control, visionary traits, resilience, and entrepreneurial competencies had an indirect effect on micro-enterprise sustainability. This finding also confirmed the mediating effect of micro-enterprise performance on the relationship between locus of control, visionary, resilience, entrepreneurial competencies, and micro-enterprise sustainability. 


\section{CONCLUSION}

When sustainable development is taken into consideration, entrepreneurship research has yet to look into firm performance and competitive advantage in details. Although the significance of firm performance is acknowledged, entrepreneurship should be able to achieve sustainable performance and serve all stakeholders. Most importantly, this study focused on the effect of entrepreneurial traits on entrepreneurial competencies, enterprise performance, and enterprise sustainability (Gerli et al., 2011). As reported by Lateh et al. (2017), entrepreneurs required specific traits and skills to run their businesses. In terms of theoretical contributions, this study extended the applicability of RBV by examining the effect of entrepreneurial traits on entrepreneurial competencies, enterprise performance, and enterprise sustainability. Specifically, this study extended other relevant studies (Barney, 1991; Grant, 1991; Lerner \& Almor, 2002; Runyan et al., 2006; Tehseen \& Ramayah, 2015; Wernerfelt, 1984) that considered entrepreneurial competencies as rare, valuable, imperfectly mobile, and non-substitutable resources that facilitate performance (competitive advantage) and sustainability (economic, social, and environmental performance).

Moreover, this study is one of the few that collected large-scale primary data of micro-enterprises in Kelantan, Malaysia. Particularly, this study examined both direct and indirect effect of locus of control, tolerance of ambiguity, visionary trait, persistence, and resilience on enterprise performance. This study also examined the indirect effect of locus of control, tolerance of ambiguity, visionary trait, persistence, and resilience on enterprise sustainability. This approach was necessary to reveal the casual relationships between the variables through rigorous analysis.

The results of path analysis and mediation test demonstrated that locus of control and visionary were resources of the firms to improve enterprise performance and sustainability directly and indirectly. Although some findings failed to support the hypotheses, resilience was found to affect neither entrepreneurial competencies nor enterprise performance. In addition, enterprise sustainability had an indirect effect, mediated by enterprise performance. According to Peterson et al. (2009), these findings are expected to enhance the understanding of psychological traits, and in turn enterprise sustainability.

In respect of practical implications, the findings are expected to improve the understanding about various factors of micro-enterprise performance and sustainability. Policymakers can utilize these findings to address the economic issues among low-income households in Kelantan. The underlying organizations should enhance locus of control, visionary, and resilience through policies, formal education, and training programs to encourage low-income households to take part in business activities. As for managers and micro-entrepreneurs, this study translates how relevant traits and competencies could be exploited to achieve competitive advantage instead of relying on the government or underlying organizations. In respect of limitations, however, this study did not incorporate other salient factors of enterprise performance and sustainability. Although this study employed an interesting data set, only a group of respondents in Kelantan was chosen, which could have limited the generalizability of the findings. Moreover, as entrepreneurial traits and competencies might differ across diverse cultures, we note that this study mostly reflect the Malaysian context translating an Asian emerging economy's perspective, which could be different than its Western developed counterparts. To address these limitations, future researchers can include new variables to increase the understanding of entrepreneurial traits, firm performance, and sustainability interplay. Future researchers can also test the applicability of the present model based on different income groups across diverse cultures.

\section{Funding}

This research was funded by the Ministry of Higher Education, Malaysia under the grant entitled "Developing a Comprehensive Rural Entrepreneurship Model for Poverty Eradication (REMODE)" (R/NRGS/A01.00/00047A/006/2014/000149). 


\section{REFERENCES}

Ahmad, N. H., Ramayah, T., Wilson, C., \& Kummerow, L. (2010). Is entrepreneurial competency and business success relationship contingent upon business environment? A study of Malaysian SMEs. International Journal of Entrepreneurial Behaviour \& Research, 16(3), 182-203. doi:10.1108/13552551011042780

Al Mamun, A., \& Fazal, S. A. (2018). Effect of entrepreneurial orientation on competency and micro-enterprise performance. Asia Pacific Journal of Innovation and Entrepreneurship., 12(3), 379-398. doi:10.1108/ APJIE-05-2018-0033

Al Mamun, A., Ibrahim, M. D., Yusoff, M. N. H. B., \& Fazal, S. A. (2018). Entrepreneurial leadership, performance, and sustainability of micro-enterprises in Malaysia. Sustainability, 10(5), 1591. doi:10.3390/ su10051591

Al-Mamun, A., Nawi, N. B. C., \& Zainol, N. R. B. (2016). Entrepreneurial Competencies and Performance of Informal Micro-Enterprises in Malaysia. Mediterranean Journal of Social Sciences, 7(3), 273-281. doi:10.5901/ mjss.2016.v7n3p273

Aldrich, H. E., \& Wiedenmayer, G. (1993). From traits to rates: An ecological perspective on organizational foundings. Advances in Entrepreneurship, Firm, Emergence, and Growth, 1(3), 145-196.

Aziz, N. N. A., Halim, R. A., \& Wahid, N. A. (2017). Networking and Innovation Performance in Micro-Enterprise in Malaysia. Advanced Science Letters, 23(8), 7374-7377. doi:10.1166/asl.2017.9478

Bagozzi, R. P., Yi, Y., \& Phillips, L. W. (1991). Assessing construct validity in organizational research. Administrative Science Quarterly, 36(3), 421-458. doi:10.2307/2393203

Barney, J. (1991). Firm resources and sustained competitive advantage. Journal of Management, 17(1), 99-120. doi:10.1177/014920639101700108

Baum, J. R., \& Locke, E. A. (2004). The relationship of entrepreneurial traits, skill, and motivation to subsequent venture growth. The Journal of Applied Psychology, 89(4), 587-598. doi:10.1037/0021-9010.89.4.587 PMID:15327346

Baum, J. R., Locke, E. A., \& Kirkpatrick, S. A. (1998). A longitudinal study of the relation of vision and vision communication to venture growth in entrepreneurial firms. The Journal of Applied Psychology, 83(1), 43-54. doi:10.1037/0021-9010.83.1.43

Baum, J. R., Locke, E. A., \& Smith, K. G. (2001). A multidimensional model of venture growth. Academy of Management Journal, 44(2), 292-303. doi:10.5465/3069456

Beattie, S. (2016). Which Entrepreneurial Traits are the Most Critical in Determining Success? Otago Management Graduate Review, 14, 13-20.

Bird, B. (1995). Towards a theory of entrepreneurial competency. Advances in Entrepreneurship, Firm, Emergence, and Growth, 2(1), 51-72.

Boone, C., Brabander, B., \& Witteloostuijn, A. (1996). CEO locus of control and small firm performance: An integrative framework and empirical test. Journal of Management Studies, 33(5), 667-700. doi:10.1111/j.1467-6486.1996.tb00814.x

Boone, C., \& VanWitteloostuijn, A. (2005). Team locus-of-control composition, leadership structure, information acquisition, and financial performance: A business simulation study. Academy of Management Journal, 48(5), 889-909. doi:10.5465/amj.2005.18803929

Bullough, A., Renko, M., \& Myatt, T. (2014). Danger zone entrepreneurs: The importance of resilience and self-efficacy for entrepreneurial intentions. Entrepreneurship Theory and Practice, 38(3), 473-499. doi:10.1111/ etap. 12006

Cardon, M. S., Wincent, J., Singh, J., \& Drnovsek, M. (2009). The nature and experience of entrepreneurial passion. Academy of Management Review, 34(3), 511-532. doi:10.5465/amr.2009.40633190

Chen, C. J., \& Huang, J. W. (2007). How organizational climate and structure affect knowledge management-The social interaction perspective. International Journal of Information Management, 27(2), 104-118. doi:10.1016/j. ijinfomgt.2006.11.001 
Chen, J. C., \& Silverthorne, C. (2008). The impact of locus of control on job stress, job performance and job satisfaction in Taiwan. Leadership and Organization Development Journal, 29(7), 572-582. doi:10.1108/01437730810906326

Chin, W. W. (1998). The partial least squares approach to structural equation modeling. Modern Methods for Business Research, 295(2), 295-336.

Chin, W. W. (2010). How to write up and report PLS analyses. In Handbook of Partial Least Squares: Concepts, Methods and Application. Esposito Vinzi. doi:10.1007/978-3-540-32827-8_29

Conger, J. A., \& Kanungo, R. N. (1994). Charismatic leadership in organizations: Perceived behavioral attributes and their measurement. Journal of Organizational Behavior, 15(5), 439-452. doi:10.1002/job.4030150508

Craig, A. R., Franklin, J. A., \& Andrews, G. (1984). A scale to measure locus of control of behaviour. The British Journal of Medical Psychology, 57(2), 173-180. doi:10.1111/j.2044-8341.1984.tb01597.x PMID:6743598

DeFillippi, R. J., \& Arthur, M. B. (1996). Boundaryless contexts and careers: A competency-based perspective. In The boundaryless career: A new employment principle for a new organizational era. Oxford University Press.

DeLuque, M. S., Washburn, N. T., Waldman, D. A., \& House, R. J. (2008). Unrequited profit: How stakeholder and economic values relate to subordinates' perceptions of leadership and firm performance. Administrative Science Quarterly, 53(4), 626-654. doi:10.2189/asqu.53.4.626

Diamantopoulos, A., \& Siguaw, J. A. (2006). Formative versus reflective indicators in organizational measure development: A comparison and empirical illustration. British Journal of Management, 17(4), $263-282$. doi:10.1111/j.1467-8551.2006.00500.x

Douglas, T. J., \& Fredendall, L. D. (2004). Evaluating the Deming management model of total quality in services. Decision Sciences, 35(3), 393-422. doi:10.1111/j.0011-7315.2004.02569.x

Driessen, M. P., \& Zwart, P. S. (2007). The entrepreneur scan measuring characteristics and traits of entrepreneurs. http://www. necarbo. eu/files/E-scan\%20MAB\%20Article.pdf

Duckworth, A. L., Peterson, C., Matthews, M. D., \& Kelly, D. R. (2007). Grit: Perseverance and passion for longterm goals. Journal of Personality and Social Psychology, 92(6), 1087-1101. doi:10.1037/0022-3514.92.6.1087 PMID: 17547490

Ellen, C., Anantadjaya, S. P., \& Saroso, T. (2014). Determinants of Entrepreneurial Success on Indonesian Food Service MSMEs. Review of Integrative Business \& Economics Research, 3(1), 81-98.

Fillis, I., \& Rentschler, R. (2010). The role of creativity in entrepreneurship. Journal of Enterprising Culture, 18(01), 49-81. doi:10.1142/S0218495810000501

Gartner, W. B. (1990). What are we talking about when we talk about entrepreneurship? Journal of Business Venturing, 5(1), 15-28. doi:10.1016/0883-9026(90)90023-M

Gerli, F., Gubitta, P., \& Tognazzo, A. (2011). Entrepreneurial competencies and firm performance: an empirical study. VIII International Workshop on Human Resource Management Conference Proceedings.

Goyal, P., \& Rahman, Z. (2014). Corporate sustainability performance and firm performance association: A literature review. International Journal of Sustainable Strategic Management, 4(4), 287-308. doi:10.1504/ IJSSM.2014.070843

Grant, R. M. (1991). The resource-based theory of competitive advantage: Implications for strategy formulation. California Management Review, 33(3), 114-135. doi:10.2307/41166664

Gualandris, J., Golini, R., \& Kalchschmidt, M. (2014). Do supply management and global sourcing matter for firm sustainability performance? An international study. Supply Chain Management, 19(3), 258-274. doi:10.1108/ SCM-11-2013-0430

Gupta, V. K., Singh, A. P., \& Singh, A. K. (2018). Role of life events stress and locus of control (external) in job satisfaction: An empirical evidence. Indian Journal of Positive Psychology, 9(1), 69-73.

Hair, J. F., Ringle, C. M., \& Sarstedt, M. (2011). PLS-SEM: Indeed a silver bullet. Journal of Marketing Theory and Practice, 19(2), 139-152. doi:10.2753/MTP1069-6679190202 
Hair, J. F. Jr, Ringle, C. M., \& Sarstedt, M. (2013). Partial least squares structural equation modeling: Rigorous applications, better results and higher acceptance. Long Range Planning, 46(1-2), 1-12. doi:10.1016/j. lrp.2013.01.001

Harman, H. H. (1976). Modern factor analysis. University of Chicago Press.

Hayton, J. C., \& Kelley, D. J. (2006). A competency-based framework for promoting corporate entrepreneurship. Human Resource Management, 45(3), 407-427. doi:10.1002/hrm.20118

Hayward, M. L., Forster, W. R., Sarasvathy, S. D., \& Fredrickson, B. L. (2010). Beyond hubris: How highly confident entrepreneurs rebound to venture again. Journal of Business Venturing, 25(6), 569-578. doi:10.1016/j. jbusvent.2009.03.002

Herman, J. L., Stevens, M. J., Bird, A., Mendenhall, M., \& Oddou, G. (2010). The tolerance for ambiguity scale: Towards a more refined measure for international management research. International Journal of Intercultural Relations, 34(1), 58-65. doi:10.1016/j.ijintrel.2009.09.004

Hill, J., \& McGowan, P. (1996). Marketing development through networking: A competency based approach for small firm entrepreneurs. Journal of Small Business and Enterprise Development, 3(3), 148-156. doi:10.1108/ eb020974

House, R. J., \& Howell, J. M. (1992). Personality and charismatic leadership. The Leadership Quarterly, 3(2), 81-108. doi:10.1016/1048-9843(92)90028-E

Ibrahim, A. B., \& Soufani, K. (2002). Entrepreneurship education and training in Canada: A critical assessment. Education + Training, 44(8/9), 421-430. doi:10.1108/00400910210449268

Jacobs, B. W., Singhal, V. R., \& Subramanian, R. (2010). An empirical investigation of environmental performance and the market value of the firm. Journal of Operations Management, 28(5), 430-441. doi:10.1016/j. jom.2010.01.001

Jing, F. F. (2017). Leadership paradigms and performance in small service firms. Journal of Management \& Organization, 1-20. doi:10.1017/jmo.2017.44

Kagbu, J. H. (2018). Constraints to women farmers' entrepreneurial development in Nasarawa State, Nigeria. Journal of Agricultural Extension, 22(1), 44-54. doi:10.4314/jae.v22i1.5

Kallaugher, J., \& Mollen, D. (2017). Student experiences of remediation in their graduate psychology programs. Training and Education in Professional Psychology, 11(4), 276-282. doi:10.1037/tep0000175

Karasinski, C., \& Anderson, K. (2017). Third Grade and Concurrent Predictors of Engagement and Achievement in Reading. Speech, Language and Hearing (London, England), 20(4), 212-222. doi:10.1080/205057 1X.2017.1290739

Kongolo, M. (2010). Job creation versus job shedding and the role of SMEs in economic development. African Journal of Business Management, 4(11), 2288-2295.

Lateh, M., Hussain, M. D., \& Halim, M. S. A. (2017). Micro Enterprise Development and Income Sustainability for Poverty Reduction: A Literature Investigation. International Journal of Business and Technopreneurship, 7(1), 23-38.

Lefcourt, H. M. (1976). Locus of control and the response to aversive events. Canadian Psychology, 17(3), 202-209. doi:10.1037/h0081839

Lerner, M., \& Almor, T. (2002). Relationships among strategic capabilities and the performance of womenowned small ventures. Journal of Small Business Management, 40(2), 109-125. doi:10.1111/1540-627X.00044

Locke, E. (2000). Motivation, cognition, and action: An analysis of studies of task goals and knowledge. Applied Psychology, 49(3), 408-429. doi:10.1111/1464-0597.00023

López, M. V., Garcia, A., \& Rodriguez, L. (2007). Sustainable development and corporate performance: A study based on the Dow Jones sustainability index. Journal of Business Ethics, 75(3), 285-300. doi:10.1007/ s10551-006-9253-8 
Man, T. W., Lau, T., \& Chan, K. F. (2002). The competitiveness of small and medium enterprises: A conceptualization with focus on entrepreneurial competencies. Journal of Business Venturing, 17(2), $123-142$. doi:10.1016/S0883-9026(00)00058-6

Man, T. W., Lau, T., \& Snape, E. (2008). Entrepreneurial competencies and the performance of small and medium enterprises: An investigation through a framework of competitiveness. Journal of Small Business and Entrepreneurship, 21(3), 257-276. doi:10.1080/08276331.2008.10593424

Masurel, E., \& Snellenberg, R. (2017). Does the lifestyle entrepreneur exists? An analysis of lifestyle entrepreneurs compared with other entrepreneurs on the basis of the development of entrepreneurial competences (Research Memorandum; Vol. 2017, No. 1). Amsterdam: School of Business and Economics.

McClelland, D. C. (1987). Characteristics of successful entrepreneurs. The Journal of Creative Behavior, 21(3), 219-233. doi:10.1002/j.2162-6057.1987.tb00479.x

McLain, D. L. (1993). The MSTAT-I: A new measure of an individual's tolerance for ambiguity. Educational and Psychological Measurement, 53(1), 183-189. doi:10.1177/0013164493053001020

Mindt, L., \& Rieckmann, M. (2017). Developing competencies for sustainability-driven entrepreneurship in higher education: A literature review of teaching and learning methods. Teoría de la Educación. Revista Interuniversitaria, 29(1), 129-159. doi:10.14201/teoredu291129159

Mintzberg, H. (1990). The design school: Reconsidering the basic premises of strategic management. Strategic Management Journal, 11(3), 171-195. doi:10.1002/smj.4250110302

Mishra, S., \& Suar, D. (2010). Does corporate social responsibility influence firm performance of Indian companies? Journal of Business Ethics, 95(4), 571-601. doi:10.1007/s10551-010-0441-1

Mitchelmore, S., \& Rowley, J. (2010). Entrepreneurial competencies: A literature review and development agenda. International Journal of Entrepreneurial Behaviour \& Research, 16(2), 92-111. doi:10.1108/13552551011026995

Mitchelmore, S., \& Rowley, J. (2013). Entrepreneurial competencies of women entrepreneurs pursuing business growth. Journal of Small Business and Enterprise Development, 20(1), 125-142. doi:10.1108/14626001311298448

Moore, S. B., \& Manring, S. L. (2009). Strategy development in small and medium sized enterprises for sustainability and increased value creation. Journal of Cleaner Production, 17(2), 276-282. doi:10.1016/j. jclepro.2008.06.004

Morgan, R. E., \& Strong, C. A. (2003). Business performance and dimensions of strategic orientation. Journal of Business Research, 56(3), 163-176. doi:10.1016/S0148-2963(01)00218-1

Mueller, S. L., \& Thomas, A. S. (2001). Culture and entrepreneurial potential: A nine country study of locus of control and innovativeness. Journal of Business Venturing, 16(1), 51-75. doi:10.1016/S0883-9026(99)00039-7

Musa, Y. (2018). An Impact of Transformational Leadership on Employees' Performance: A Case Study in Nigeria. In V. Bhateja, B. Nguyen, N. Nguyen, S. Satapathy, \& D. N. Le (Eds.), Information Systems Design and Intelligent Applications. Advances in Intelligent Systems and Computing (Vol. 672). Springer. doi:10.1007/978981-10-7512-4_70

Nabiswa, F., \& Mukwa, J. S. (2017). Impact of credit financing on human resource development among micro and small enterprises: A case study of Kimilili Sub County, Kenya. Asian Journal of Management Science and Economics, 4(1), 43-53.

Naffziger, D. (1995). Entrepreneurship: A person based theory approach. Advances in Entrepreneurship, Firm, Emergence, and Growth, 2, 21-50.

Niedbala, E. M., \& Feinberg, J. (2017). Cross-Cultural Competencies for the NASA International Internship Project. NTRS Report No: ARC-E-DAA-TN45142. NASA.

Onstenk, J. (2003). Entrepreneurship and vocational education. European Educational Research Journal, 2(1), 74-89. doi:10.2304/eerj.2003.2.1.12

Pendergast, W. R. (2003). Entrepreneurial Contexts and Traits of Entrepreneurs. Proceedings of Teaching Entrepreneurship to Engineering Students. Available at: https://services.bepress.com/eci/teaching 
Peng, D. X., \& Lai, F. (2012). Using partial least squares in operations management research: A practical guideline and summary of past research. Journal of Operations Management, 30(6), 467-480. doi:10.1016/j. jom.2012.06.002

Peterson, S. J., Walumbwa, F. O., Byron, K., \& Myrowitz, J. (2009). CEO positive psychological traits, transformational leadership, and firm performance in high-technology start-up and established firms. Journal of Management, 35(2), 348-368. doi:10.1177/0149206307312512

Podsakoff, P. M., MacKenzie, S. B., Lee, J. Y., \& Podsakoff, N. P. (2003). Common method biases in behavioral research: A critical review of the literature and recommended remedies. The Journal of Applied Psychology, 88(5), 879-903. doi:10.1037/0021-9010.88.5.879 PMID:14516251

Powell, T. C., Lovallo, D., \& Caringal, C. (2006). Causal ambiguity, management perception, and firm performance. Academy of Management Review, 31(1), 175-196. doi:10.5465/amr.2006.19379630

Rahman, Z. (2016). The difficulties faced by micro and small enterprises in the formal market access: The case in small and micro enterprises in the cities of Makassar and Kabupaten Gowa south Sulawesi. International Journal of the Humanities, 4(1), 92-103.

Raymond, L., Marchand, M., St-Pierre, J., Cadieux, L., \& Labelle, F. (2013). Dimensions of small business performance from the owner-manager's perspective: A re-conceptualization and empirical validation. Entrepreneurship and Regional Development, 25(5-6), 468-499. doi:10.1080/08985626.2013.782344

Reinartz, W., Haenlein, M., \& Henseler, J. (2009). An empirical comparison of the efficacy of covariance-based and variance-based SEM. International Journal of Research in Marketing, 26(4), 332-344. doi:10.1016/j. ijresmar.2009.08.001

Rotter, J. B. (1966). Generalized expectancies for internal versus external control of reinforcement. Psychological Monographs, 80(1), 1-28. doi:10.1037/h0092976 PMID:5340840

Runyan, R. C., Huddleston, P., \& Swinney, J. (2006). Entrepreneurial orientation and social capital as small firm strategies: A study of gender differences from a resource-based view. The International Entrepreneurship and Management Journal, 2(4), 455-477. doi:10.1007/s11365-006-0010-3

Sánchez, J. C. (2013). The impact of an entrepreneurship education program on entrepreneurial competencies and intention. Journal of Small Business Management, 51(3), 447-465. doi:10.1111/jsbm.12025

Santos, S. C., Caetano, A., \& Curral, L. (2013). Psychosocial aspects of entrepreneurial potential. Journal of Small Business and Entrepreneurship, 26(6), 661-685. doi:10.1080/08276331.2014.892313

Sarasvathy, S. D., \& Venkataraman, S. (2011). Entrepreneurship as method: Open questions for an entrepreneurial future. Entrepreneurship Theory and Practice, 35(1), 113-135. doi:10.1111/j.1540-6520.2010.00425.x

Searcy, C. (2016). Measuring Enterprise Sustainability. Business Strategy and the Environment, 25(2), 120-133. doi:10.1002/bse. 1861

Shane, S., Locke, E. A., \& Collins, C. J. (2003). Entrepreneurial motivation. Human Resource Management Review, 13(2), 257-279. doi:10.1016/S1053-4822(03)00017-2

Simpson, M., Taylor, N., \& Barker, K. (2004). Environmental responsibility in SMEs: Does it deliver competitive advantage? Business Strategy and the Environment, 13(3), 156-171. doi:10.1002/bse.398

Sitkin, S. B., \& Pablo, A. L. (1992). Reconceptualizing the determinants of risk behavior. Academy of Management Review, 17(1), 9-38. doi:10.5465/amr.1992.4279564

Smith, B. W., Dalen, J., Wiggins, K., Tooley, E., Christopher, P., \& Bernard, J. (2008). The brief resilience scale: Assessing the ability to bounce back. International Journal of Behavioral Medicine, 15(3), 194-200. doi:10.1080/10705500802222972 PMID:18696313

Steyn, Z., \& VanStaden, L. J. (2018). Investigating selected self-management competencies of managers. Acta Commercii, 18(1), 1-10. doi:10.4102/ac.v18i1.530

Tarabishy, A., Solomon, G., Fernald, L. W. Jr, \& Sashkin, M. (2005). The entrepreneurial leader's impact on the organization's performance in dynamic markets. Journal of Private Equity, 8(4), 20-29. doi:10.3905/ jpe.2005.580519 
Tedeschi, R. G., \& Calhoun, L. G. (2004). Posttraumatic growth: Conceptual foundations and empirical evidence. Psychological Inquiry, 15(1), 1-18. doi:10.1207/s15327965pli1501_01

Tehseen, S., \& Ramayah, T. (2015). Entrepreneurial competencies and SMEs business success: The contingent role of external integration. Mediterranean Journal of Social Sciences, 6(1), 50-61. doi:10.5901/mjss.2015.v6n1p50

Thompson, J. L. (1999). A strategic perspective of entrepreneurship. International Journal of Entrepreneurial Behaviour \& Research, 5(6), 279-296. doi:10.1108/13552559910306105

Tubbs, S. L., \& Schulz, E. (2006). Exploring a taxonomy of global leadership competencies and metacompetencies. The Journal of American Academy of Business, Cambridge, 8(2), 29-34.

Ţuţu, A., \& Constantin, T. (2012). Understanding job performance through persistence and job competency. Procedia: Social and Behavioral Sciences, 33, 612-616. doi:10.1016/j.sbspro.2012.01.194

Urban, B. (2008). Social entrepreneurship in South Africa: Delineating the construct with associated skills. International Journal of Entrepreneurial Behaviour \& Research, 14(5), 346-364. doi:10.1108/13552550810897696

Venkatraman, N., \& Ramanujam, V. (1986). Measurement of business performance in strategy research: A comparison of approaches. Academy of Management Review, 11(4), 801-814. doi:10.5465/amr.1986.4283976

Wagener, S., Gorgievski, M., \& Rijsdijk, S. (2010). Businessman or host?Individual differences between entrepreneurs and small business owners in the hospitality industry. Service Industries Journal, 30(9), $1513-1527$. doi:10.1080/02642060802624324

Wahid, N. A., Aziz, N. N. A., \& Halim, R. A. (2017). Networking and Innovation Performance of MicroEnterprises in Malaysia: The Moderating Effects of Geographical Location. Perrtanika Journal of Social Sciences \& Humanities, 25(S), 281-292.

Walczak, R., \& Derbis, R. (2017). Podstawowe samowartościowanie-walidacja polskiej wersji skali do pomiaru Core Self-Evaluations. Czasopismo Psychologiczne- Psychological Journal, 23(1), 147-158.

Wernerfelt, B. (1984). A resource-based view of the firm. Strategic Management Journal, 5(2), 171-180. doi: $10.1002 /$ smj.4250050207

Wold, H. (1975). Path models with latent variables: The NIPALS approach. In Quantitative sociology (pp. 307-357). Academic Press. doi:10.1016/B978-0-12-103950-9.50017-4

Yorulmaz, Ö. G. R., \& Erdem, R. (2017). Hastane çaliganlarinda kontrol odağinin öz ve kolektġf yeterlġlġk üzerg்ne etkg்sg. Suleyman Demirel University Visionary Journal, 8(19), 77-92.

Zimmer, C. (1986). Entrepreneurship through social networks. In The art and science of entrepreneurship. Ballinger.

\footnotetext{
Abdullah Al Mamun currently works at the UCSI Graduate Business School, Faculty of Business and Management, UCSI University, Malaysia since January 2020 as Associate Professor. Previously he worked at the Faculty of Entrepreneurship and Business, Universiti Malaysia Kelantan as Senior Lecturer (2012-2019). He completed his MBA and PhD from the Multimedia University, Malaysia, in 2007 and 2012, respectively. His research interest includes development economics, entrepreneurship, and environmental economics. He received 18 grants, published seven books and more than 170 articles. He was the founding Managing Editor of Journal of Entrepreneurship and Business published by Universiti Malaysia Kelantan. He is an Editor of the special issue of the journal Transnational Corporations Review, Member of Editorial Review Board of the Journal of Entrepreneurship in Emerging Economies, and Article Editor of the journal SAGE Open. He was the recipient of the University Excellent Service Award for Publication in 2014 - 2018 from Universiti Malaysia Kelantan, Malaysia. He was the member of Asian Academy of Management (2015-2017) and American Economic Association (2014-2020).
} 